\title{
PENDEKATAN KEARIFAN LOKAL UNTUK MENINGKATKAN KEMAMPUAN APRESIASI SENI MAHASISWA PGSD FKIP UNIVERSITAS RIAU
}

\author{
Zariul Antosa ${ }^{1}{ }^{*}$, Muhammad Fendrik ${ }^{2}$, Lazim. $\mathbf{N}^{3}$ \\ 1 Universitas Riau \\ 2 Universitas Riau \\ ${ }^{3}$ Universitas Riau
}

\begin{abstract}
Abstrak
The problem inthis studyis the lack ofability to appreciate the art work on PGSD FKIPUR students who can be seen insymptoms symptoms of inability to distinguish works of craft and art works, the low ability students explain the function and meaning of craft objects in public life in accordance with the local culture local. Lack of student awards both morally and materially to the creation of creative crafts. lack of abilityin the understanding of concepts, reasoning, and problem solving, artcrafts. Based on the problems it is necessary to find away to solve the problem. Among themis to change the methods of teaching. For that in this study the researcher will apply local knowledge in the learning approach. This research was conductedasa classaction two cycles each cycleconsisted of two meetings. The application of local wisdom approach in volvesa conscious effort to engage students actively and creatively. Subjects in this study were students PGSD FKIP-UR fourth semester. Research data collection instruments consisted of observation activity sheets and sheets of faculty and students to replay the end of thetest cycle. The study was a classroom action research (CAR), this study aims to increase art appreciation fourth semester students PGSDFKIP-UR. The results of this study indicate that the application of local wisdom approach can improve student art appreciation PGSD FKIP-UR, with the average value of the initial value of 58.41 into a 84.75 in the second cycle. The average value of faculty activity also increased from an average of68.15 into 94.75. Student Activities also increased from an average of $63.24 \%$ in the first cycle to $89.80 \%$. Thus,the research hypothesis when applied local wisdom, the ability to approa chart appreciation PGSD FKIP-UR students increased, proven.
\end{abstract}

Keywords:

Local Wisdom, Art

Appreciation

\section{PENDAHULUAN}

Pengembangan sumber daya manusia saat ini masih menjadi tanda tanya besar. Lembaga pendidikan sebagai penghasil sumber daya manusia masih belum mampu menjawab tantangan tersebut. Usaha pemeritah melalui pengembangan kurikulum yang adaptif dengan tuntutan kebutuhan pembangunan nasional, serta peningkatan kualitas dan kuantitas sarana dan prasarana belajar sudah cukup baik.Seharusnya lulusan lembaga pendidikan sudah mampu berperan aktif dan produktif dalam melaksanakan pembangunan.Namun sementara inihal itu belum terjadi seperti yang diharapkan. Peningkatan sarana dan prasarana belajar belum jadi jaminan untuk meningkatkan sumber daya manusia.

Sarana dan prasarana belajar yang lengkap akan efektif dalam mencapai tujuan perkuliahan jikadosen sebagai motor perkuliahan berperan aktif dan inovatif dalam mengimplementasikan kurikulum, sehingga ketersediaan sarana dan prasarana belajar efektif meningkatkan sumber daya manusia yang cakap dan adaptif terhadap kebutuhan pembangunan dapat diciptakan.

Dalam GBHN dinyatakan bahwa tujuan pendidikan antara lain adalah mendorong berkembangnya kreatifitas peserta didik. Pendidikan seni merupakan salah satu materi ajar yang dikembangkan pemerintah untuk meningkatkan kreativitas. Dalam Kurikulum KTSP 2006 dikatakan, pendidikan seni bertujuan untuk menumbuhkembangkan sikap kreatif dan budaya daerah dalam membina perkembangan budaya nasional. Apresiasi seni merupakan bagian integral dalam pendidikan 
seni karena apresiasi seni menjadi wahana bagi mahasiswa untuk berargumen dan menaggapi perkembangan budaya serta kreativitas seni sehingga semua pengembangan sumber daya yang ada dapat terkontrol sesuai dengan tuntutan budaya daerah dan nasional. Secara konseptual apresiasi seni berfungsi untuk mengembangkan sikap dan sensitivitas mahasiswa dalam berkarya.

Berdasarkan hasil observasi dan wawancara yang peneliti lakukan pada beberapa mahasiswa PGSD FKIP-UR, tentang tanggapan mereka terhadap perkuliahan seni dan budaya daerah padakegiatan perkuliahan Pendidikan Seni Kerajinan belum memberikan gambaran pemahaman yang menyeluruh terhadap seni kerajian daerah maupun nasional. Karya kerajinan hanya dipahami sebagai sebagai sebuah artefak yang bermakna pakai. Mahasiswa belum mampu melihat makna-makna lain pada karya kerajinan daerah. Hal ini belum menunjukkan capaian maksimal sesuai dengan tujuan kurikulum.Berdasarkan hasil observasi diketahui terdapat4mahasiswa yang memiliki apresiasi baik8 orang cukup dan 22 orang mahasiswamemiliki apresiasi rendah, kebanyakan mahasiswa masih kurang mampu mengapresiasi karya kerajinan. Hal ini terlihat dari gejala gejala sebagai berikut: Rendahnya pemahaman mahasiswa terhadap karya kerajinan hal ini terlihat dari ketidak mampuan membedakan karya kerajinan dan karya seni rupa, rendahnya kemampuan mahasiswa menjelaskan fungsi dan makna benda-benda kerajinan dalam kehidupan masyarakat sesuai dengan budaya daerah setempat. Kurangnya penghargaan mahasiswa baik moril maupun materil terhadap kreatifitas penciptaan benda kerajinan. rendahnya kemampuan dalam pemahaman konsep, penalaran, dan memecahkan masalah, tentang seni kerajinan.

Untuk melaksanakan perkuliahan yang mampu mengatasi masalah di atas, perlu dicari satu strategi perkuliahan yang dapat menumbuhkembangkan apresiasi mahasiswa terhadap karya kerajinan. Meningkatkan peran aktif mahasiswa dalam memahami karya kerajinan sebagai sebuah karya cipta manusia yang tidak hanya diciptakan sebagai fungsi guna saja.

\section{METODE PENELITIAN}

Penelitian ini dilaksanakan di PGSD FKIP-UR, waktu penelitian dilaksanakan pada bulan Mei sampai bulan Juni 2014. Subjek penelitian mahasiswasemeseter IV PGSD FKIP-UR sebanyak 34 orang yang terdiri dari 5mahasiswa laki-laki dan 29mahasiswa perempuan. Desain penelitian ini adalah penelitian tindakan semester (PTK) yang terdiri dari 2 siklus, setiap siklus terdiri dari 2 kali pertemuan. Data yang dikumpulkan dalam penelitian ini berupa data tentang aktivitas memberikan perkuliahanoleh peneliti dan aktivitas mahasiswa dengan penerapan pendekatan kearifan lokaldalam mata kuliah pendidikan seni kerajinan. Data penelitian dikumpulkan dengan menggunakan teknik observasi dan teknik tes. Teknik observasi digunakan untuk mengumpulkan data aktivitas pelaksanaan perkuliahan oleh dosen (peneliti) dan data aktivitas mahasiswa. Sedangkan teknik tes digunakan untuk mengetahui kemampuan apresiasi mahasiswa terhadap seni kerajinan

\section{ANALISIS DAN PEMBAHASAN}

Pelaksanaan tindakan dilakukan sebanyak dua siklus masing masing siklus terdiri dari dua kali pertemuan dengan penerapan pendekatan kearifan lokal dalam kegiatan perkuliahan. Tindakan dilakukan dengan tujuan untuk meningkatkan kemampuan apresiasi mahasiswa PGSD FKIP-UR. Adapun pelaksanaan tindakan dalam penelitian ini adalah sebagai berikut :

\section{Tindakan Siklus I}

Perencanaan

Pelaksanaan tindakan pada siklus I dilakukan dalam dua kali pertemuan perkuliahan, siklus pertama terdiri dari dua kali penyampaian materi dan pada akhir pertemuan ke dua dilakukan evaluasi. Pada siklus kedua juga terdiri dari dua kali penyampaian materi dan diakhiri dengan evaluasi. Dalam penelitian ini peneliti bertindak sebagai pelaksana penelitian dan dosensejawat bertindak sebagai pengamat atau observer untuk mengamati kegiatan perkuliahan selama peneliti melakukan tindakan perkuliahan dengan pendekatan kearifan lokal. Pada setiap akhir perkuliahan peneliti dan observer berdiskusi tentang kekurangan dan kelebihan yang terdapat pada proses tindakan yang telah dilakukan. Hasil observasi digunakn sebagai acuan dalam merencanakan tindakan untuk pertemuan selanjutnya. Diakhir siklus pertama dilakukan refleksi yang bertujuan untuk perbaikan sampai terjadi peningkatan dalam proses perkuliahan.

\section{Pertemuan Pertama}

Kegiatanperkuliahan yang dilakukan dosen berpedoman pada perencanaan yang telah dibuat. Pada awal perkuliahandosen membuka kegiatan pembelajaran dengan memberikan pengantar dan halhal yang akan dilakukan mahasiswa, menyiapkan mahasiswa dan media. Perkuliahan diawali dengan mengenalkan karya-karya kerajinan setempat. Mahasiswa disuruh mengamati media dan dilanjutkan 
dengan curah pendapat tentang pengalaman siswa terkait dengan contoh kerajinan pada media yang ditampilkan. Pada waktu bersamaan oeneliti menceritakan komponen apa yang harus menjadi titik perhatian mahasiswa. Selanjutnya mahasiswa berusaha menemukan fungsi praktis dan fungsi sosial dari benda-benda tersebut serta fungsi spritual yang mereka ketahui berkaitan dengan budaya setempat. Masing-masing mahasiswa dituntut merumuskan hasil pengamatan dalam bentuk tertulis. Hasil tulisan mahasiswa dikonfrontir dengan hasil kerja mahasiswa lainnya untuk mendapatkan keberagaman informasi. Terakhir mahasiswa menguji hasil rumusan mereka dengan sumber-sumber yang telah peneliti sediakan dari berbagai sumber.

\section{Pengamatan aktivitas dosen}

Pengamatan aktivitas dosen dilakukan oleh dosen selama proses perkuliahan berlangsung. Observer duduk di bangku paling belakang dan mengamati aktivitas dosen sampai perkuliahan selesai. Observer mengamati aktivitas dosen yang dilakukan peneliti dengan mengisi lembar observasi aktivitas dosen. Skor yang menjadi acuan hasil observasi merujuk ke kriteria penilaian aktivitas dosen yang telah disiapkan sebelumnya.

\section{Pengamatan aktivitas mahasiswa}

Pengamatan aktivitas mahasiswa juga dilakukan selama proses perkuliahan berlangsung. Observer disamping mengamati peneliti juga mengamati mahasiswa sampai perkuliahan selesai. Observer mengamati aktivitas mahasiswaselama peneliti melakukan tindakan perkuliahan dengan mengisi lembar observasi aktivitas mahasiswa. Skor yang menjadi acuan merujuk ke tahapan apresiasi yang telah disiapkan sebelumnya

\section{Pertemuan Kedua}

Tahap pelaksanaan tindakan pada pertemuan ke dua dengan penerapan pendekatan kearifan lokal dilakukan dengan kegaiatan praktek. Pada pertemuan ke dua mahasiswa diperlihatkan dua buah benda kerajinan daerah setempat. Pertemuan kedua dilaksanakan pada hari Senin tanggal 19 Mei 2014 selama 3 jam tatap muka (3x55 menit). Mahasiswa dibagi menjadi dua kelompok dan masing-masing kelompok diberi sebuah benda kerajinan daerah setempat (anyaman). Mahasiswadisuruh mengamati media dan dilanjutkan dengan curah pendapat dalam kelompok meraka tentang pengalaman merekaterhadap media yang ditampilkan. Selama proses pengamatan dan curah pendapat masing-masing anggota kelompk merumuskan hasil pengamatannya dengan bahasa sendiri dengan melihat fungsi praktis dan fungsi sosial dari benda-benda tersebut serta fungsi spritual yang mereka ketahui berkaitan dengan budaya setempat. Masing-masing mahasiswa dituntut menceritakan hasil pengamatannya. Informasi yang disampaikan mahasiswa dikonfrontir dengan hasil kerja mahasiswa lainnya untuk mendapatkan keberagaman informasi. Terakhir mahasiswa menguji hasil rumusan mereka dengan sumber-sumber yang telah peneliti sediakan dari berbagai sumber.

\section{Refleksi Siklus I}

Berdasarkan hasil pengamatan observer terlihat aktivitas dosen pada siklus I dengan menggunakan pendekatan kearifan lokalsudah terlaksana sesuai dengan yang direncanakan walaupun masih terdapat kekurangan dalam segi pengolaan kelompok dan bimbingan. Beberapa kekurangannya yaitu: Peneliti kurang efektif mengelola kegiatan mahasiswa dalam pembelajaran sehingga mahasiswa menjadi ribut, Peneliti kurang efektif mengatur waktu sehingga pada saat diskusi banyak mahasiswa yang tidak dapat kesempatan dalam mengemukakan pendapatnya. Dalam kerja kelompok masih terdapat mahasiswa yang belum bisa bekerjasama. Karena pada saat itu sebagian anggota kelompok mengerjakan pekerjaan lain dan sering kali pembicaraan mereka dari kerangka yang sudah ditentukan dalam kegiatan diskusi, Peneliti kurang memotivasi mahasiswa agar mahasiswa lebih kreativ dan terampil dalam mencermati.

\section{Pelaksanaan Tindakan Siklus II \\ Pertemuan Pertama}

Pelaksanaan tindakan pada pertemuan pertama siklus II dilaksanakan pada hari senin tanggal 26 Mei 2014 selama 3 jam perkuliahan. dengan materi apresiasi karya kerajinan nusantara yaitu karya kerajinan anyaman Jawa Barat, Sumatera Barat, Papua dan Kalimantan Selatan. Tindakan dilakukan dengan membagi mahasiswa menjadi 4 kelompok. Masing-masing kelompok mendapat satu karya kerajinan anyaman dan mahasiswa disuruh mengamati media dan dilanjutkan dengan curah pendapat tentang pengalaman siswa terkait dengan media yang mereka dapatkan. Pada waktu bersamaan peneliti menyuruh siswa merumuskan hasil taggapannya sesuai dengan dengan rambu-rambu yang telah disiapkan, mahasiswa berusaha menemukan fungsi praktis dan fungsi sosial dari benda-benda tersebut serta fungsi spritual dan mendeskripsikannya. Masing-masing mahasiswa dituntut merumuskan hasil pengamatan dalam bentuk tertulis. Hasil tulisan mahasiswa ditukar dengan kelompok lain. Terakhir mahasiswa menuliskan tanggapannya terhadap lembar kerja yang telah ditulis oleh kelompok lain 
sambilmenguji hasil rumusan mereka dengan sumber-sumber yang telah peneliti sediakan dari berbagai sumber.

\section{Pertemuan kedua}

Pertemuan kedua dilaksanakan pada hari Senin tanggal 2 juni 2014 selama 3 jam tatap muka (3x55 menit). Mahasiswa dibagi menjadi 4 kelompok dan masing-masing kelompok diberi sebuah benda kerajinan nusantara tapi berbeda dengan yang dibahas pada pertemuan pertama. Masing-masing mahasiswa disuruh mengamati media dan dilanjutkan dengan curah pendapat dalam kelompok mereka berkaitan dengan pengalaman mereka terhadap media yang ditampilkan. Selama proses pengamatan dan curah pendapat masing-masing anggota kelompok merumuskan hasil pengamatannya dengan bahasa sendiri dengan melihat fungsi praktis dan fungsi sosial dari benda kerajinan tersebut serta fungsi spritual yang mereka ketahui berkaitan dengan budaya setempat. Selanjutnya mahasiswa kembali ketempat duduk masing-masing dan dosen memanggil mahasiswa secara acak dan diminta memberikan tanggapan terhadap karya kerajinaan secara verbal di depan kelas. Masing-masing mahasiswa dituntut menceritakan hasil pengamatannya. Informasi yang disampaikan mahasiswa dikonfrontir dengan tanggapan mahasiswa lainnya. Terakhir mahasiswa menguji hasil rumusan mereka dengan sumber-sumber yang telah disediakan.

\section{Refleksi Siklus II}

Setelah pelaksanaan tindakan siklus II pertemuan 2 peneliti kembali mengadakan diskusi dengan observer. Pembelajaran sudah terlaksana sesuai dengan yang direncanakan tapi masih terdapat beberapa kekurangan pada pengolaan kelompok dan pelaksanaan persentasi. Kekurangan itu diantaranya adalah yaitu: Peneliti kurang merespon beberapa tanggapan mahasiswayang menyimpang sedangkan tanggapan tersebut berpotensi untuk terjadi kesalahan dalam mengapresiasi. Peneliti masih kurang efektif mengatur waktu sehingga pada saat diskusi banyak mahasiswa yang tidak dapat kesempatan dalam mengemukakan pendapatnya. Peneliti kurang memotivasi mahasiswa agar mahasiswa lebih kreativ dan terampil dalam mencermati.

\section{Analisis Hasil Penelitian}

Data hasil observasi siklus I dan siklus II tentang aktivitas dosen, siklus I dan siklus II dapat dilihat pada Tabel 1 berikut:

Tabel 1

Aktivitas Dosen Selama Proses Perkuliahan Pada Penerapan Pendekatan kearifan lokal Siklus I dan Siklus II

\begin{tabular}{llrrrcc}
\hline \multirow{2}{*}{ NN } & \multirow{2}{*}{ Aktivitas dosen yang diamati } & \multicolumn{2}{c}{ pertemuan } & \multicolumn{2}{c}{ Pertemuan } \\
o & & I & II & I & II \\
\hline & & 19 & 22 & 24 & 26 \\
& Jumlah & 68,15 & 78,5 & 85,71 & 94,75 \\
Skor & Baik & Baik & tmat baik Amat baik \\
Kategori & & \multicolumn{3}{c}{} \\
\hline
\end{tabular}

Dari tabel 1 di atas dapat dilihat bahwa secara umum aktivitas dosen selama empat kali pertemuan mengalami peningkatan. Pada aktivitas dosen pada siklus Idan IIdenganskor 94,75. Jadi secara keseluruhan aktivitas dosen dari pertemuan pertama hingga pertemuan keempat dalam proses perkuliahan sudah sesuai dengan perencanaan

\section{Aktivitas Mahasiswa Dalam Proses Perkuliahan}

Tabel 2

Perbandingan Aktivitas Mahasiswa Selama Proses Perkuliahan Pada Penerapan Pendekatan kearifan lokalSiklus I dan Siklus II

\begin{tabular}{|c|c|c|c|c|c|}
\hline \multirow[t]{2}{*}{ No } & \multirow{2}{*}{$\begin{array}{c}\text { Aktivitas mahasiswa yang } \\
\text { diamati }\end{array}$} & \multicolumn{2}{|c|}{$\begin{array}{c}\text { I } \\
\text { pertemuan }\end{array}$} & \multicolumn{2}{|c|}{$\begin{array}{c}\text { II } \\
\text { pertemuan }\end{array}$} \\
\hline & & $\mathrm{I}$ & II & $\mathrm{I}$ & II \\
\hline & Jumlah & 16 & 19 & 22 & 24 \\
\hline & Persentase & $63,24 \%$ & $69,8 \%$ & $78,5 \%$ & $89,80 \%$ \\
\hline & Kategori & Cukup & Baik & Baik & Amat Baik \\
\hline
\end{tabular}


Dari tabel 2 di atas dapat dilihat bahwa terjadi peningkatan aktivitas mahasiswa disetiap pertemuan pertama hingga pertemuan keempat dengan skor 63,24\% pada siklus pertama menjadi 89,80\% pada siklus kedua.

\section{Hasil Kemampuan ApresiasiMahasiswa}

Dari hasilkemampuanmahasiswa siklus I dan siklus II, pada siklus I dari jumlah keseluruhan 34 orang mahasiswa, yang mendapat kategori terampil 26 orang, cukup terampil sebanyak 8 orang. Sedangkan pada siklus II meningkat mahasiswa yang mendapat ketegori sangat terampil 10 orang dan kategori terampil 23 orang dan cukup terampil 1 orang.

Pembahasan Hasil Tindakan

Berdasarkan hasil analisis data siklus I dan siklus II maka penerapan pendekatan kearifan lokaldalam meningkatkan kemampuan apresiasimahasiswa dapat meningkatkan beberapa hal sebagai berikut:

\section{Peningkatan Aktivitas Dosen}

Pada lembar pengamatan aktivitas dosen, pada siklus I skor peningkatan aktivitas dosen adalah 10,6 (Baik)sedangkan pada siklus II dengan skor 7,14 (Amat baik).

\section{Peningkatan Aktivitas Mahasiswa}

Pada lembar pengamatan aktivitas mahasiswa, dari siklus 1 persentase peningkatan mahasiswa adalah 10,66\% (Baik) sedangkan pada siklus ke II menjadi 7,21\% (Amat Baik).

\section{Peningkatan Hasil Kemampuan apresiasi}

Untuk mengetahui peningkatan kemampuan apresiasimahasiswa dari siklus I ke siklus II setelah penerapan pendekatan kearifan lokal mahasiswa semester IV PGSD FKIP-UR tahun pelajaran 2013-2014 dapat dilihat pada Tabel 3 di bawah ini

Tabel 3

Peningkatan Nilai Kemampuan apresiasiMahasiswa pada Data Awal, Siklus I, dan Siklus II

\begin{tabular}{clccc}
\hline \multicolumn{1}{c}{ Interval } & \multicolumn{1}{c}{ Kategori } & \multicolumn{2}{c}{ Kemampuan apresiasi } \\
& & Dt Awal & UH I & UH II \\
\hline $81,25 \geq<100$ & Sangat Terampil & - & - & 10 \\
$62,5 \geq<81,25$ & Terampil & 14 & 26 & 23 \\
$43,75 \geq<62,5$ & Cukup Terampil & 17 & 8 & 1 \\
$25 \geq<43,75$ & Kurang Terampil & 3 & - & - \\
$\quad$ Jumlah Mahasiswa & & 34 & 34 & 34 \\
Nilai rata-rata mahasiswa & 58,41 & 70,67 & 84,75 \\
\hline
\end{tabular}

Untuk lebih jelasnya peningkatan kemampuan apresiasi dapat dilihat pada grafik dibawah ini:

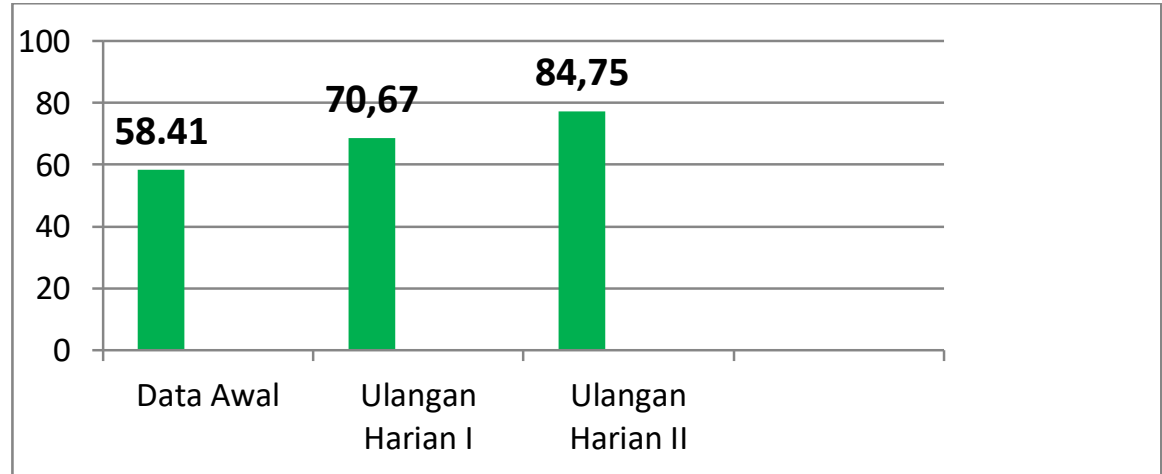

Gambar. 1

Grafik Peningkatan Kemampuan ApresiasiMahasiswaSemesterIV PGSD FKIP-UR Dari Data Awal, Siklus I dan Siklus II

Secara keseluruhan peningkatan kemampuanmahasiswadari data awal demgan nilai rata-rata mahasiswa 58,41 menjadi nilai 84,75 pada siklus II. Untuk lebih jelasnya peningkatan kemampuan apresiasi pada data awal, siklus I, siklus II dapat dilihat pada grafik di bawah ini.

\section{KESIMPULAN}


Berdasarkan analisis hasil penelitian yang telah diuraikan pada bab IV dapat disimpulkan bahwa pendekatan kearifan lokal dapat meningkatkan kemampuan apresiasi mahasiswa PGSD FKIP-UR. Hal ini terbukti dari hasilanalisis data penelitian sebagai berikut: 1) Peningkatan Aktivitas dosen yaitu dari siklus I pertemuan pertama dengan skor 68,15 meningkat menjadi 94,75 pada siklus ke II, 2) Peningkatan aktivitas mahasiswa yaitu dari siklus I pertemuan pertama dengan persentase $63,24 \%$ kemudian meningkat pada pertemuan kedua siklus ke II dengan persentase $89,80 \%$, 3) Peningkatan kemampuanapresiasi mahasiswadari data awal dengan nilai rata-rata 58,41 meningkat pada siklus II menjadi 84,75.

Saran yang peneliti ajukan sehubungan dengan penerapan pendekatan kearifan lokal untuk meningkatkan kemampuan apresiasi mahasiswa PGSD FKIP UR pada mata kuliah Pendidikan Seni kerajinan maka peneliti menyarankan sebagai berikut: 1) Bagi mahasiswa sebagai proses yang dapat dikembangkan untuk memahami materi perkuliahan lainnya terutama materi kuliah yang berkaitan deangan budaya, 2) Bagi dosen dapat menggunakan hasil penelitian sebagai informasi dalam memilih strategi pembelajaran. Terutama dalam pembelajaran yang berhubungan dengan ilmu-ilmu humaniora khususnya ilmu budaya. Bagi Program Studi Pendidikan Guru Sekolah Dasar dapat menggunakan informasi ini sebagai informasi dalam mengembangkan metode-metode mengajar

\section{DAFTAR PUSTAKA}

Akhmad, Sudarajat 2008 Perkuliahan Kontekstual. (online). Sumber: http://id.shvoong.com/businessmanagement/humanresources/2197108-pengertian Kontekstual/. (20Maret 2014)

Ayat Rohaidi, 1986. Local Genius Alfabeta , Jakarta

Daryanto.2009. Panduan Proses Perkuliahan Kreatif dan Inovatif. Jakarta : publisher

Dimyati dan Mudjiono. 2006. Belajar dan Perkuliahan. Jakarta: Rineka Cipta

Emmons, R. A. \& Mc.Cullough, M.E. (Ed.) (2004). The Psychology of Gratitude. new York: Oxford University Press.Tersedia: http:/www.questia.com. [28 Mei 2005].

KTSP. 2006. Kurikulum Tingkat Satuan Pendidikan. Jakarta : Bahan Standar Nasional Pendidikan.

Mulyasa, 2010. Praktik Penelitian Tindakan Semester. Bandung : Remaja Rosda KaryaPengertian karya. http://id.shvoong.com/exact-sciences/biology/2168299-pengertian-karya-sastra/. maret 2014)

Pengertian kerajinan. http://id.wikipedia.org/wiki/kerajinan. (20 Maret 2014)

S. T. Alisjahbana. (1983). Kreativitas. Jakarta: Dian Rakyat.

Satria, 2008 Kemampuan. ( online ). Sumber: http://id.shvoong.com/business-management/humanresources/2197108-pengertian-kemampuan-danjenisnya/\#ixzzluZ69b7MR. $\quad(20$ Maret 2014)

Setyawan, Barmin, Eko. 2009. Seni Budaya dan Kemampuan. Solo : Tiga Serangkai

Soehardjo, A. J. (2005). Pendidikan Seni, dari Konsep sampai Program. Malang: Balai Kajian Seni dan Desain Jurusan Seni dan Desain Fakultas Sastra Universitas Negeri Malang.

Suharsimi Arikunto,2009. Penelitian Tindakan Semester. Jakarta : Bumi Aksara

Sumanto,2006. Derektorat Jenderal Pendidikan Tinggi, Jakarta. Pengembangan Kreativitas Seni Rupa Anak Sekolah Dasar.Tim Bina Karya Dosen, ( 2006 ), Seni Budaya dan Kemampuan (Untuk Sekolah Dasar Semester V), Erlangga, Jakarta.

Tukiran Taniredja.,2011. Model Model Perkuliahan Inovatif. Bandung : Alfabeta

Udin Saefudin, Sa'ud.,2008. Inovasi Pendidikan. Bandung : Alfabeta

Usman Husaini.,2008. Metodologi Penelitian Sosial. Jakarta : Bumi Aksara

Wina Sanjaya, 2007. Strategi Perkuliahan Berorientasi Estandar Proses Pendidikan. Jakarta : Kencana 